\title{
Probability Aspects of Entrance Exams at University
}

\author{
Jindrich Klufa \\ Department of Mathematics, University of Economics, Czech Republic \\ Received October 30, 2019; Revised December 24, 2019; Accepted January 13, 2020
}

Copyright $\bigcirc 2020$ by authors, all rights reserved. Authors agree that this article remains permanently open access under the terms of the Creative Commons Attribution License 4.0 International License

\begin{abstract}
The entrance examinations tests were shorted from 50 questions to 40 questions at the Faculty of International Relations at University of Economics in Prague due to time reasons. These tests are the multiple choice question tests. The multiple choice question tests are suitable for entrance examinations at University of Economics in Prague - the tests are objective and results can be evaluated quite easily and quickly for large number of students. On the other hand, a student can obtain certain number of points in the test purely by guessing the right answers. This shortening of the tests from 50 questions to 40 questions has negative influence on the probability distributions of number of points in the tests (under assumption of the random choice of answers). Therefore, this paper is suggested a solution of this problem. The comparison of these three ways of acceptance of applicants to study the Faculty of International Relations at University of Economics from probability point of view is performed in present paper. The results of this paper show that there has been a significant improvement of the probability distributions of number of points in the tests. The obtained conclusions can be used for admission process at the Faculty of International Relations in coming years.
\end{abstract}

Keywords Distribution Function, Entrance Exams, Expected Value, Median, Mode, Standard Deviation

\section{Introduction}

Students of University of Economics in Prague are accepted to study on the basis of tests in English and mathematics. Two different tests (the multiple choice question tests) in English at the university are applied in admission process in present time:

Test 1 . The test has 50 questions for 2 points (100 points total). Questions are independent. Each question has 4 answers (one answer is correct), wrong answer is not penalized.

Test 2. The test has 40 questions for 2.5 points (100 points total). Questions are independent. Each question has 4 answers (one answer is correct), wrong answer is not penalized.
The Test 2 is applied in admission process at the Faculty of International Relations, the Test 1 is applied in admission process at the Faculty of Informatics and Statistics, at the Faculty of Business Administration and at the Faculty of Finance and Accounting. The Test 2 has only 40 questions since entrance exams at the Faculty of International Relations have three parts (mathematics, English and other language).

The multiple choice question tests are suitable for the admission process at Prague University of Economics (statistical analysis of the tests at University of Economics we can find in Klůfa (2015b), Otavová and Sýkorová (2014)). The tests are objective and results can be evaluated easily for large number of students. On the other hand, a student can obtain certain number of points in the test purely by guessing the right answers. The problem is solved in Zhao (2005), Premadasa (1993), Zhao (2006) - this article studies the probability of obtaining a certain score by pure guesswork and introduces a conversion scheme which converts raw test scores into standard percentage marks (the probabilistic analysis shows that the optimum number of choices of answers is four). The admission process is addressed e.g. in following education research. Dependence of the results of entrance examinations on test variants is analysed in Klůfa (2015a). Relation between results of the entrance exam test and university study results at Charles University (Faculty of Mathematics and Physics) is studied in Zvára and Anděl (2001). The same problem at Czech University of Life Sciences is studied in Poláčková and Svatošová (2013). Similar problems are solved in Bartoška, Brožová, Šubrt and Rydval (2013), Flégl et al. (2014), Hrubý (2016), Otavová and Sýkorová (2016), Krejčí et al. (2011), Brožová and Rydval (2014), Flégl et al. (2013), Ječmínek et al. (2018). Comparison of the Test 1 in English and the Test 2 in English at University of Economics from probability point of view is provided in this paper. Moreover, we shall suggest Test 3 to improve the probability distributions of number of points in the tests in English.

Test 3. The test has 40 questions for 2.5 points (100 points total). Questions are independent. Each question has 5 answers (one answer is correct), wrong answer is not penalized.

The Test 3 has the same number of questions (due to time 
reasons) but each question has 5 answers (the Test 2 has only 4 answers). This paper is significant extension of the paper Klůfa (2018) - moreover the Test 3 in English was suggested and analysed.

\section{Material and Methods}

The tests in English correspond to the following general model: Let us consider $n$ independent random trials having two possible outcomes, say "success" (right answer) and "failure" (wrong answer) with probabilities $p$ and $(1-p)$ respectively. The probability of correctly answered question $p$ (under assumption that each of $m$ answers in particular question has the same probability and just one answer is correct) is $p=1 / \mathrm{m}$.

Let us denote $X$ as number of successes (right answers) that occur in $n$ independent random trials. $X$ is discrete random variable distributed according to the binomial law with parameters $n$ and $p$. Probability that number of successes is $k(k=0,1,2, \ldots, n)$ is (see e.g. Rao (1973))

$$
P(X=k)=\left(\begin{array}{l}
n \\
k
\end{array}\right) p^{k}(1-p)^{n-k}
$$

The expected value and the standard deviation of random variable $X$ distributed according the binomial law with parameters $n$ and $p$ is

$$
E(X)=n p, \quad \sigma(X)=\sqrt{D(X)}=\sqrt{n p(1-p)}
$$

where $D(X)$ is dispersion of random variable $X$.

The distribution function $F$ of random variable $X$ is a real function of one real variable defined for $x$ in interval $(-\infty, \infty)$ by formula

$$
F(x)=P(X \leq x)
$$

i.e. $F(x)$ is a probability that number of correct answers is less or equal to $x$. In our case, the distribution function $F$ of random variable $X$ distributed according to the binomial law with parameters $n$ and $p$ is

$$
F(x)=0, x<0, F(x)=\sum_{k=0}^{[x]}\left(\begin{array}{l}
n \\
k
\end{array}\right) p^{k}(1-p)^{n-k}, x \geq 0
$$

where $[x]$ is integer part of $x$. The median of random variable $X$ is the central value $\tilde{x}(F(\tilde{x})=0.5)$, for the binomial distribution is not uniquely determined. The mode of random variable $X$ is the most probable value $\hat{x}$ of random variable $X$.

\section{Results and Discussion}

\subsection{Distribution of the Number of Points in the Test 1 in English}

Now we shall study the distribution of the number of points in the Test 1 (the test has 50 questions for 2 points) in English. Discrete random variable

$$
Z_{1}=\text { number of points in the Test } 1 \text { in English }
$$

can take values

$$
0,2,4,6,8,10,12,14, \ldots, 98,100
$$

For determination of distribution random variable $Z_{1}$ we must find the probability $P\left(Z_{1}=k\right)$ for $k=0,2,4,6$, $8, \ldots, 98,100$. For example, we shall find probability that number of points in Test 1 in English is 20. Let us denote

$$
S=\text { number of right answers in the } 50 \text { issues }
$$

Under assumption that each answer has a same probability (the random choice of answers), probability of right answer is $p=1 / 4$. Therefore, random variable $S$ has binomial distribution with parameters $n=50$ and

\begin{tabular}{|c|c|c|c|}
\hline Points in Test 1 & Probability & Points in Test 1 & Probability \\
\hline 0 & 0.000001 & 36 & 0.026390 \\
\hline 2 & 0.000009 & 38 & 0.014816 \\
\hline 4 & 0.000077 & 40 & 0.007655 \\
\hline 6 & 0.000411 & 42 & 0.003645 \\
\hline 8 & 0.001610 & 44 & 0.001602 \\
\hline 10 & 0.004938 & 46 & 0.000650 \\
\hline 12 & 0.012345 & 48 & 0.000244 \\
\hline 14 & 0.025865 & 50 & 0.000084 \\
\hline 16 & 0.046341 & 52 & 0.000027 \\
\hline 18 & 0.072087 & 54 & 0.000008 \\
\hline 20 & 0.098518 & 56 & 0.000002 \\
\hline 22 & 0.119416 & 58 & 0.000001 \\
\hline 24 & 0.129368 & 60 & $1 \times 10^{-7}$ \\
\hline 26 & 0.126050 & 62 & $3 \times 10^{-8}$ \\
\hline 28 & 0.111044 & 64 & $6 \times 10^{-9}$ \\
\hline 30 & 0.088836 & 66 & $1 \times 10^{-9}$ \\
\hline 32 & 0.064776 & $* * *$ & $* * *$ \\
\hline 34 & 0.043184 & Sum & 1.000000 \\
\hline
\end{tabular}
$p=0.25$. According to (1) we obtain

$$
P\left(Z_{1}=20\right)=P(S=10)=\left(\begin{array}{l}
50 \\
10
\end{array}\right) 0.25^{10} \quad 0.75^{40}=0.098518 .
$$

Other probabilities are in Tab. 1 (only for $k=0, .66$, other probabilities are less than $10^{-9}$ ) - see also Fig. 1 .

Table 1. Distribution of number of points in Test 1 in English (source: own calculation)

Now we shall find the distribution function $F_{1}$ of random variable $Z_{1}$ (number of points in the Test 1 in English). For example we shall find the probability that number of points in Test 1 in English is less or equal 30, i.e. the function value $F_{1}(30)$. We have

$$
\begin{gathered}
F_{1}(30)=P\left(Z_{1} \leq 30\right)=P\left[\left(Z_{1}=0\right) \cup\left(Z_{1}=2\right)\right. \\
\left.\cup\left(Z_{1}=4\right) \cup \ldots \cup\left(Z_{1}=28\right) \cup\left(Z_{1}=30\right)\right]
\end{gathered}
$$

Random events $\left(Z_{1}=0\right),\left(Z_{1}=2\right),\left(Z_{1}=4\right), \ldots,\left(Z_{1}=\right.$ $28),\left(Z_{1}=30\right)$ are disjoint (i.e. these random events cannot occur simultaneously), therefore

$$
\begin{gathered}
P\left(Z_{1} \leq 30\right)=P\left(Z_{1}=0\right)+P\left(Z_{1}=2\right)+P\left(Z_{1}=4\right)+\cdots \\
+P\left(Z_{1}=28\right)+P\left(Z_{1}=30\right)
\end{gathered}
$$




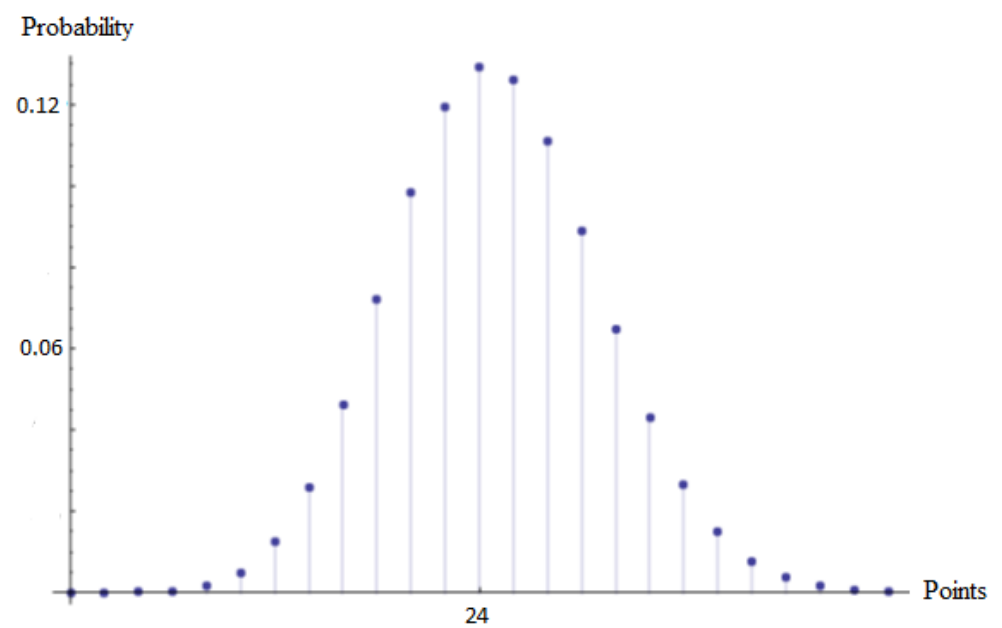

Figure 1. Distribution of number of points in Test 1 in English (source: own construction)

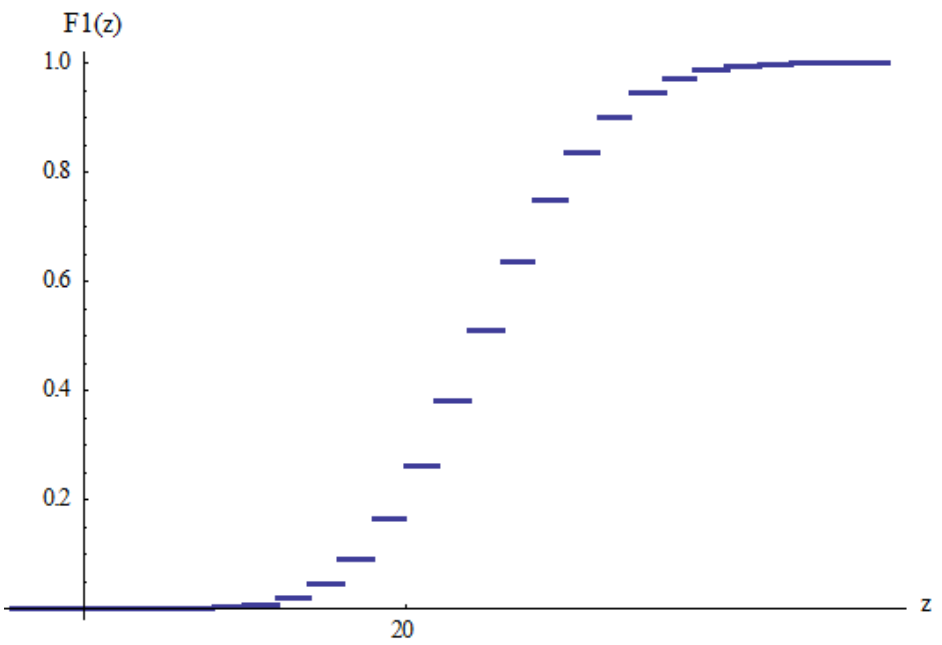

Figure 2. Distribution function of number of points in Test 1 in English (source: own construction)

Finally, from Table 1, we obtain

$$
F_{1}(\mathbf{3 0})=P\left(Z_{1} \leq \mathbf{3 0}\right)=0.836916
$$

i.e. under assumption of random choice of answers approximately $83.7 \%$ of students get the test score less or equal 30. Similarly we can find other values of distribution function $F_{1}-$ see Table 2.

Finally, we shall find a basic descriptive statistics of the distribution of the number of points in the Test 1 in English. According to (2) we obtain the expected number of points in Test 1 in English. Since $Z_{1}=2 S$ we have

$$
E\left(Z_{1}\right)=E(2 S)=2 E(S)=2 * 50 * 0.25=25 .
$$

Expected number of points in Test 1 in English is 25. The mode of this distribution is the most probable number of points in Test 1 in English. From Tab. 1 is $\hat{z}_{1}=24$. Similarly, we find the median (central value, $F(z)=0.5$ ) of number of points in Test 1. From Tab. 2 is approximately $\tilde{z}_{1} \approx 24$.

Dispersion of number of points in Test 1 in English is according to (2)

$$
D\left(Z_{1}\right)=D(2 S)=2^{2} D(S)=4 * 9.375=37.5
$$

and the standard deviation of number of points in Test 1 in English is $\sigma_{\mathbf{1}}=\mathbf{6 . 1 2 4}$.
Table 2. Distribution function of number of points in Test 1 in English (source: own calculation)

\begin{tabular}{|c|c|c|c|}
\hline $\begin{array}{c}\text { Interval of values } \\
\mathrm{z}\end{array}$ & $F_{I}(\mathrm{z})$ & $\begin{array}{c}\text { Interval of values } \\
\mathrm{z}\end{array}$ & $F_{I}(\mathrm{z})$ \\
\hline$(-\infty, 0)$ & 0 & {$[34,36)$} & 0.944876 \\
\hline$[0,2)$ & 0.000001 & {$[36,38)$} & 0.971266 \\
\hline$[2,4)$ & 0.000010 & {$[38,40)$} & 0.986082 \\
\hline$[4,6)$ & 0.000087 & {$[40,42)$} & 0.993737 \\
\hline$[6,8)$ & 0.000498 & {$[42,44)$} & 0.997382 \\
\hline$[8,10)$ & 0.002108 & {$[44,46)$} & 0.998984 \\
\hline$[10,12)$ & 0.007046 & {$[46,48)$} & 0.999634 \\
\hline$[12,14)$ & 0.019391 & {$[48,50)$} & 0.999878 \\
\hline$[14,16)$ & 0.045256 & {$[50,52)$} & 0.999962 \\
\hline$[16,18)$ & 0.091597 & {$[52,54)$} & 0.999989 \\
\hline$[18,20)$ & 0.163684 & {$[54,56)$} & 0.999997 \\
\hline$[20,22)$ & 0.262202 & {$[56,58)$} & 0.999999 \\
\hline$[22,24)$ & 0.381618 & {$[58,60)$} & 1.000000 \\
\hline$[24,26)$ & 0.510986 & {$[60,62)$} & 1.000000 \\
\hline$[26,28)$ & 0.637036 & {$[62,64)$} & 1.000000 \\
\hline$[28,30)$ & 0.748080 & {$[64,66)$} & 1.000000 \\
\hline$[30,32)$ & 0.836916 & $* * *$ & $* * *$ \\
\hline$[32,34)$ & 0.901692 & {$[100, \infty)$} & 1 \\
\hline & & & \\
\hline
\end{tabular}




\subsection{Distribution of the Number of Points in the Test 2 in English}

Now we shall study the distribution of the number of points in the Test 2 (the test has 40 questions for 2.5 points) in English. Discrete random variable

$$
Z_{2}=\text { number of points in the Test } 2 \text { in English }
$$

can take values

$0, \quad 2.5, \quad 5, \quad 7.5, \quad 10, \quad 12.5, \quad 15,17.5, \ldots, 97.5,100$

For determination of distribution random variable $Z_{2}$ we must find the probability $P\left(Z_{2}=k\right)$ for $k=0,2.5,5$, $7.5, \ldots, 97.5,100$. For example we shall find probability that number of points in Test 2 in English is 20. Let us denote

$$
T=\text { number of right answers in the } 40 \text { issues }
$$

Under assumption that each answer has a same probability (the random choice of answers), probability of right answer is $p=1 / 4$. Therefore, random variable $T$ has binomial distribution with parameters $n=40$ and $p=0.25$. According to (1) we obtain

$$
P\left(Z_{2}=20\right)=P(T=8)=\left(\begin{array}{c}
40 \\
8
\end{array}\right) 0.25^{8} \quad 0.75^{32}=0.117878 .
$$

Analogously, we can calculate the probability $P\left(Z_{2}=\right.$ $k$ ) for other $k=0,2.5,5, \ldots, 97.5,100$ - see Tab.3 (only for $k=0, \ldots, 67,5$, other probabilities are less than $\left.10^{-8}\right)$ and Fig.3.

Table 3. Distribution of number of points in Test 2 in English (source: own calculation)

\begin{tabular}{|c|c|c|c|}
\hline Points in Test 2 & Probability & Points in Test 2 & Probability \\
\hline 0 & 0.000010 & 37.5 & 0.028192 \\
\hline 2.5 & 0.000134 & 40 & 0.014684 \\
\hline 5 & 0.000872 & 42.5 & 0.006910 \\
\hline 7.5 & 0.003680 & 45 & 0.002943 \\
\hline 10 & 0.011347 & 47.5 & 0.001136 \\
\hline 12.5 & 0.027232 & 50 & 0.000398 \\
\hline 15 & 0.052951 & 52.5 & 0.000126 \\
\hline 17.5 & 0.085730 & 55 & 0.000036 \\
\hline 20 & 0.117878 & 57.5 & 0.000009 \\
\hline 22.5 & 0.139707 & 60 & 0.000002 \\
\hline 25 & 0.144364 & 62.5 & $5 \times 10^{-7}$ \\
\hline 27.5 & 0.131240 & 65 & $9 \times 10^{-8}$ \\
\hline 30 & 0.105721 & 67.5 & $2 \times 10^{-8}$ \\
\hline 32.5 & 0.075903 & $* * *$ & $* * *$ \\
\hline 35 & 0.048795 & Sum & 1.000000 \\
\hline & & & \\
\hline
\end{tabular}

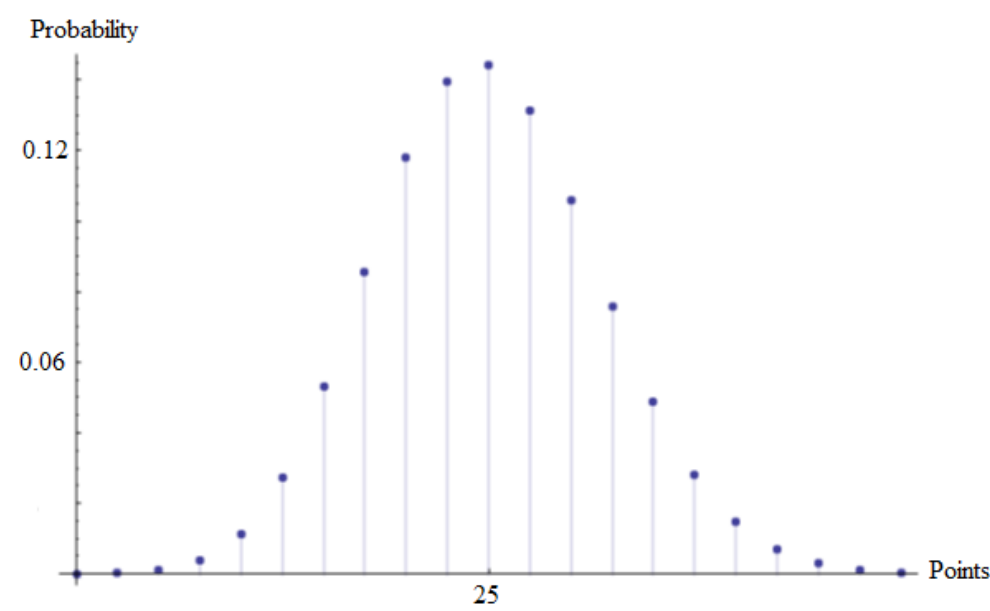

Figure 3. Distribution of number of points in Test 2 in English (source: own construction) 
Now we shall find the distribution function $F_{2}$ of random variable $Z_{2}$ (number of points in the Test 2 in English). For example we shall calculate the probability that number of points in the Test 2 in English is less or equal 30 , i.e. the function value $F_{2}(30)$. We have

$$
\begin{gathered}
F_{2}(30)=P\left(Z_{2} \leq 30\right)=P\left(Z_{2}=0\right)+P\left(Z_{2}=2.5\right) \\
+\cdots+P\left(Z_{2}=27.5\right)+P\left(Z_{2}=30\right)
\end{gathered}
$$

Finally, from Tab. 3, we obtain

$$
\boldsymbol{F}_{\mathbf{2}}(\mathbf{3 0})=\boldsymbol{P}\left(\boldsymbol{Z}_{\mathbf{2}} \leq \mathbf{3 0}\right)=0.820866,
$$

i.e. under assumption of random choice of answers approximately $82.1 \%$ of students get the test score less or equal 30. Similarly we can find other values of distribution function $F_{2}$ - see Tab. 4 .

Finally, we shall find a basic descriptive statistics of the distribution of the number of points in the Test 2 in English. According to (2) we obtain the expected number of points in the Test 2 in English. Since $Z_{2}=2.5 T$ we have

$$
E\left(Z_{2}\right)=E(2.5 T)=2.5 \quad E(T)=2.5 * 40 * 0.25=25 .
$$

Expected number of points in the Test 2 in English is 25. The mode is the most probable number of points. From Tab. 3 is $\hat{z}_{2}=25$. Similarly, we find the median of number of points in the Test 2 in English. From Tab. 4 is approximately $\tilde{z}_{2} \approx 24$.

Dispersion of number of points in the Test 2 in English is according to (2)
$D\left(Z_{2}\right)=D\left(\begin{array}{ll}2.5 & T\end{array}\right)=2.5^{2} \quad D(T)=6.25 * 7.5=46.875$ and the standard deviation of number of points in the Test 2 in English is $\sigma_{2}=\mathbf{6 . 8 4 7}$.

Table 4. Distribution function of number of points in Test 2 in English (source: own calculation)

\begin{tabular}{|c|c|c|c|}
\hline $\begin{array}{c}\text { Interval of values } \\
\mathrm{z}\end{array}$ & $F_{2}(\mathrm{z})$ & $\begin{array}{c}\text { Interval of values } \\
\mathrm{z}\end{array}$ & $F_{2}(\mathrm{z})$ \\
\hline$(-\infty, 0)$ & 0 & {$[35,37.5)$} & 0.945564 \\
\hline$[0,2.5)$ & 0.000010 & {$[37.5,40)$} & 0.973756 \\
\hline$[2.5,5)$ & 0.000144 & {$[40,42.5)$} & 0.988440 \\
\hline$[5,7.5)$ & 0.001016 & {$[42.5,45)$} & 0.995350 \\
\hline$[7.5,10)$ & 0.004696 & {$[45,47.5)$} & 0.998293 \\
\hline$[10,12.5)$ & 0.016043 & {$[47.5,50)$} & 0.999429 \\
\hline$[12.5,15)$ & 0.043275 & {$[50,52.5)$} & 0.999827 \\
\hline$[15,17.5)$ & 0.096226 & {$[52.5,55)$} & 0.999953 \\
\hline$[17.5,20)$ & 0.181956 & {$[55,57.5)$} & 0.999989 \\
\hline$[20,22.5)$ & 0.299834 & {$[57.5,60)$} & 0.999998 \\
\hline$[22.5,25)$ & 0.439541 & {$[60,62.5)$} & 1.000000 \\
\hline$[25,27.5)$ & 0.583905 & {$[62.5,65)$} & 1.000000 \\
\hline$[27.5,30)$ & 0.715145 & {$[65,67.5)$} & 1.000000 \\
\hline$[30,32.5)$ & 0.820866 & $* * *$ & $* * *$ \\
\hline$[32.5,35)$ & 0.896769 & {$[100, \infty)$} & 1 \\
\hline
\end{tabular}

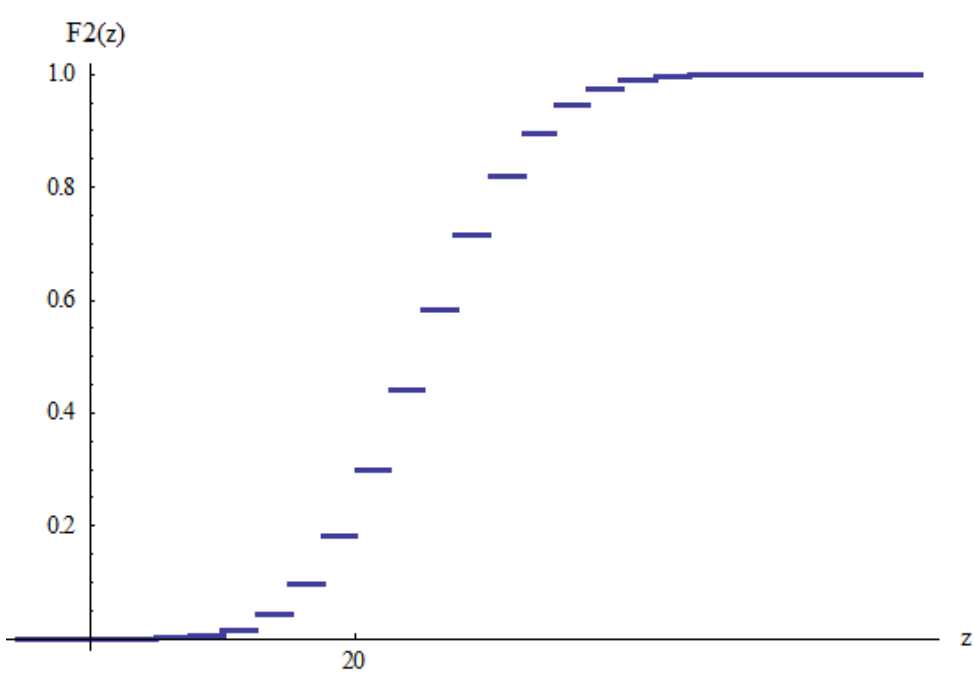

Figure 4. Distribution function of number of points in Test 2 in English (source: own construction) 
Comparison of the Test 1 and the Test 2 in English is in Tab. 5. For example, test score more than 30 points in the Test 1 has $16.3 \%$ of students, since (see Tab. 2)

$P\left(Z_{1}>30\right)=1-F_{1}(30)=1-0.836916=0.163084$

Table 5. Comparison of the tests in English - random choice of answers (source: own calculation)

\begin{tabular}{|c|c|c|}
\hline $\begin{array}{c}\text { Entrance examination in } \\
\text { English }\end{array}$ & Test 1 & Test 2 \\
\hline $\begin{array}{c}\text { Expected number of points } \\
\text { in test }\end{array}$ & 25 & 25 \\
\hline Mode & 6.124 & 25 \\
\hline Standard deviation & $\begin{array}{c}99.3 \% \text { of } \\
\text { students }\end{array}$ & $\begin{array}{c}98.4 \% \text { of } \\
\text { students }\end{array}$ \\
\hline $\begin{array}{c}\text { Test score more than } 10 \\
\text { points }\end{array}$ & $\begin{array}{c}73.8 \% \text { of } \\
\text { students }\end{array}$ & $\begin{array}{c}70.0 \% \text { of } \\
\text { students }\end{array}$ \\
\hline $\begin{array}{c}\text { Test score more than } 20 \\
\text { points }\end{array}$ & $\begin{array}{c}16.3 \% \text { of } \\
\text { students }\end{array}$ & $\begin{array}{c}17.9 \% \text { of } \\
\text { students }\end{array}$ \\
\hline $\begin{array}{c}\text { Test score more than } 30 \\
\text { points }\end{array}$ & $\begin{array}{c}0.62 \% \text { of } \\
\text { students }\end{array}$ & $\begin{array}{c}1.16 \% \text { of } \\
\text { students }\end{array}$ \\
\hline Test score more than 40 \\
points
\end{tabular}

The Distribution 1 (the distribution of number of points in the Test 1 in English) and the Distribution 2 (the distribution of number of points in the Test 2 in English) have the same expected value (see Tab. 5). Standard deviation of the Distribution 2 is greater than standard deviation of the Distribution 1 (the mode is greater as well). Due to greater variability of the Distribution 2 e.g. the probability that number of points in the Test 2 in English exceeds 40 is approximately two times greater (see Tab. 5) than the probability that number of points in Test 1 in English exceeds 40. From the results, it follows that the probability distribution of number of points in English in the Test 2 worsened after the test was shortened. Therefore, we shall suggest the Test 3 to improve the probability distributions of number of points in the tests in English. The solution of this problem is in next section.

\subsection{Distribution of the Number of Points in the Test 3 in English}

The Test 3 has the same number of questions (due to time reasons) but each question has 5 answers (the Test 2 has only 4 answers). Let us denote

$$
Z_{3}=\text { number of points in the Test } 3 \text { in English }
$$

Discrete random variable $Z_{3}$ can take values
$0, \quad 2.5, \quad 5,7.5,10,12.5,15,17.5, \ldots, 97.5,100$

For determination of probability distribution of random variable $Z_{3}$, we must find the probability $P\left(Z_{3}=k\right)$ for $k=0,2.5,5,7.5, \ldots, 97.5,100$. For example, we shall find probability that number of points in the Test 3 in English is 30. Let us denote $T=$ number of right answers in the 40 issues. Under assumption that each answer has a same probability (the random choice of answers), probability of right answer is $p=1 / 5$. Therefore, random variable $T$ has binomial distribution with parameters $n=40$ and $p=0.2$. According to (1) we obtain

$$
\begin{gathered}
P\left(Z_{3}=30\right)=P(T=12)=\left(\begin{array}{l}
40 \\
12
\end{array}\right) 0.2^{12} 0.8^{28} \\
=0.044264 .
\end{gathered}
$$

For comparison: The probability that number of points in the Test 2 in English is 30 points (see Table 3) is 0.105721 . The probability that number of points in the Test 3 in English is 30 points (under the random choice of answers) is significant less than for the Test 2. It seems that the Test 3 will be better than the Test 2. Analogously, we can calculate the probability $P\left(Z_{3}=k\right)$ for other $k=0,2.5$, $5, \ldots, 97.5,100$ - see Tab. 6 (only for $k=0, \ldots, 67,5$, other probabilities are less than $10^{-11}$ ) and Fig. 5.

Table 6. Distribution of number of points in Test 3 in English (source: own calculation)

\begin{tabular}{|c|c|c|c|}
\hline Points in Test 3 & Probability & Points in Test 3 & Probability \\
\hline 0 & 0.000133 & 37.5 & 0.004980 \\
\hline 2.5 & 0.001329 & 40 & 0.001945 \\
\hline 5 & 0.006480 & 42.5 & 0.000687 \\
\hline 7.5 & 0.020520 & 45 & 0.000219 \\
\hline 10 & 0.047452 & 47.5 & 0.000063 \\
\hline 12.5 & 0.085414 & 50 & 0.000017 \\
\hline 15 & 0.124563 & 52.5 & 0.000003 \\
\hline 17.5 & 0.151255 & 55 & $9 \times 10^{-7}$ \\
\hline 20 & 0.155981 & 57.5 & $2 \times 10^{-7}$ \\
\hline 22.5 & 0.138650 & 60 & $3 \times 10^{-8}$ \\
\hline 25 & 0.107454 & 62.5 & $5 \times 10^{-9}$ \\
\hline 27.5 & 0.073264 & 65 & $7 \times 10^{-10}$ \\
\hline 30 & 0.044264 & 67.5 & $9 \times 10^{-11}$ \\
\hline 32.5 & 0.023834 & $* * *$ & $* * *$ \\
\hline 35 & 0.011492 & Sum & 1.000000 \\
\hline & & & \\
\hline
\end{tabular}




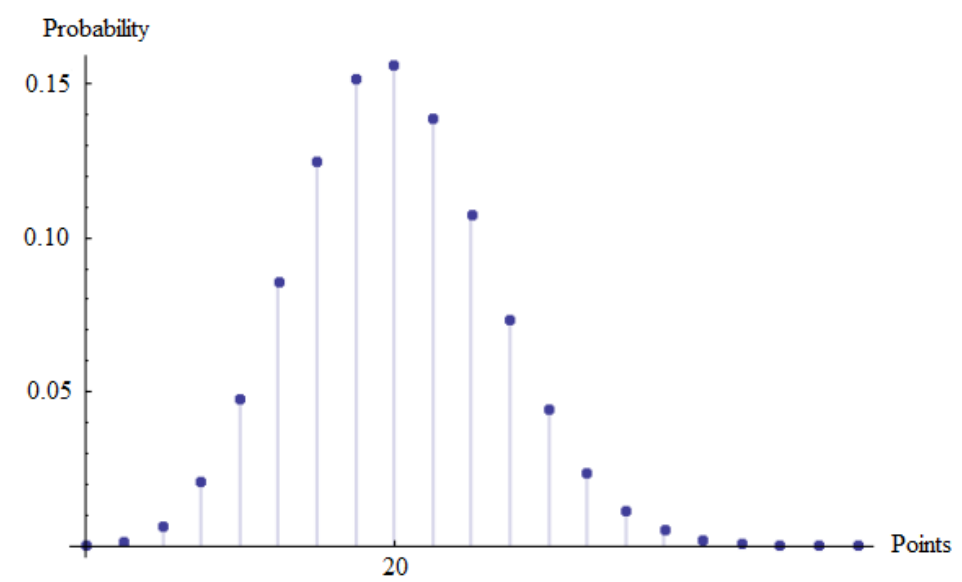

Figure 5. Distribution of number of points in Test 3 in English (source: own construction)

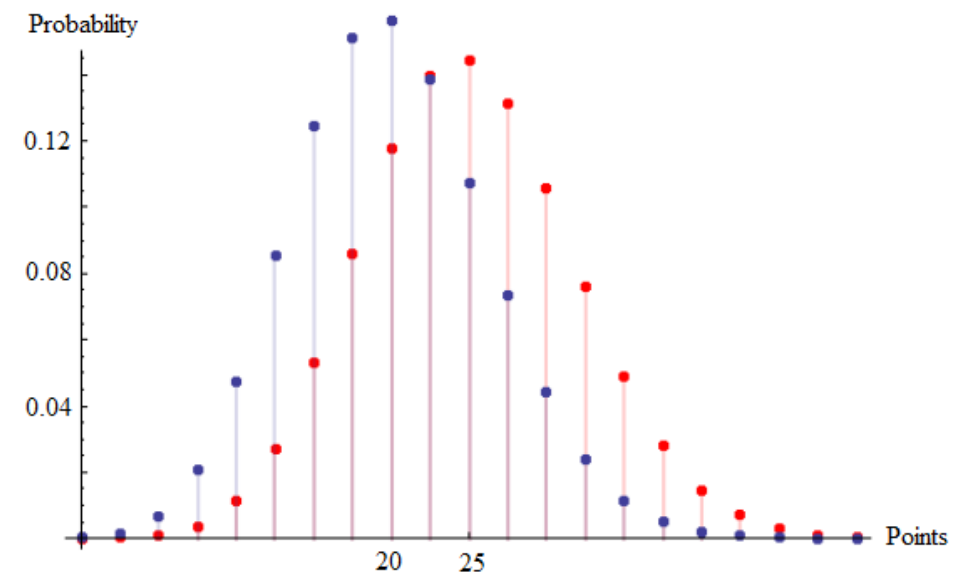

Figure 6. Comparison of distributions of number of points in Test 2 (red) and Test 3 (blue) (source: own construction)

From Figure 6, you can very well see that the Test 3 has improved the probability distribution of number of points in the tests in English. Now we shall find the distribution function $F_{3}$ of random variable $Z_{3}$ (number of points in the Test 3 in English). For example, we shall calculate the probability that number of points in the Test 3 in English is less or equal 20 , i.e. the function value $F_{3}(20)$. We have

$$
\begin{aligned}
F_{3}(20) & =P\left(Z_{3} \leq 20\right)=P\left(Z_{3}=0\right)+P\left(Z_{3}=2.5\right) \\
& +\cdots+P\left(Z_{3}=17.5\right)+P\left(Z_{3}=20\right)
\end{aligned}
$$

Finally, from Tab. 6, we obtain

$$
F_{3}(20)=P\left(Z_{3} \leq 20\right)=0.593127,
$$

i.e. under assumption of random choice of answers approximately $59.3 \%$ of students get the test score less or equal 20. Similarly we can find other values of distribution function $F_{3}-$ see Tab. 7 .

Finally, we shall find a basic descriptive statistics of the distribution of the number of points in the Test 3 in English. According to (2) we obtain the expected number of points in the Test 3 in English. Since $Z_{3}=2.5 T$ we have

$$
E\left(Z_{3}\right)=E(2.5 T)=2.5 E(T)=2.5 * 40 * 0.2=20 .
$$

Expected number of points in the Test 3 in English is 20. For comparison: Expected number of points in the Test 2 in English (under the random choice of answers) is 25, i.e. expected number of points in the Test 3 is less than expected number of points in the Test 2 . The mode is the most probable number of points. From Tab. 6 is $\hat{z}_{3}=20$. Similarly, we find the median of number of points in test 3 in English. From Tab. 7 is approximately $\tilde{z}_{3} \approx 19$.

Table 7. Distribution function of number of points in Test 3 in English (source: own calculation)

\begin{tabular}{|c|c|c|c|}
\hline $\begin{array}{c}\text { Interval of values } \\
\mathrm{z}\end{array}$ & $F_{3}(\mathrm{z})$ & $\begin{array}{c}\text { Interval of values } \\
\mathrm{z}\end{array}$ & $F_{3}(\mathrm{z})$ \\
\hline$(-\infty, 0)$ & 0 & {$[35,37.5)$} & 0.992085 \\
\hline$[0,2.5)$ & 0.000133 & {$[37.5,40)$} & 0.997065 \\
\hline$[2.5,5)$ & 0.001462 & {$[40,42.5)$} & 0.999010 \\
\hline$[5,7.5)$ & 0.007942 & {$[42.5,45)$} & 0.999697 \\
\hline$[7.5,10)$ & 0.028462 & {$[45,47.5)$} & .999916 \\
\hline$[10,12.5)$ & 0.075914 & {$[47.5,50)$} & 0.999979 \\
\hline$[12.5,15)$ & 0.161328 & {$[50,52.5)$} & 0.999996 \\
\hline$[15,17.5)$ & 0.285891 & {$[52.5,55)$} & 0.999999 \\
\hline$[17.5,20)$ & 0.437146 & {$[55,57.5)$} & 1.000000 \\
\hline$[20,22.5)$ & 0.593127 & {$[57.5,60)$} & 1.000000 \\
\hline$[22.5,25)$ & 0.731777 & {$[60,62.5)$} & 1.000000 \\
\hline$[25,27.5)$ & 0.839231 & {$[62.5,65)$} & 1.000000 \\
\hline$[27.5,30)$ & 0.912495 & {$[65,67.5)$} & 1.000000 \\
\hline$[30,32.5)$ & 0.956759 & $* * *$ & $* * *$ \\
\hline$[32.5,35)$ & 0.980593 & {$[100, \infty)$} & 1 \\
\hline & & & \\
\hline
\end{tabular}




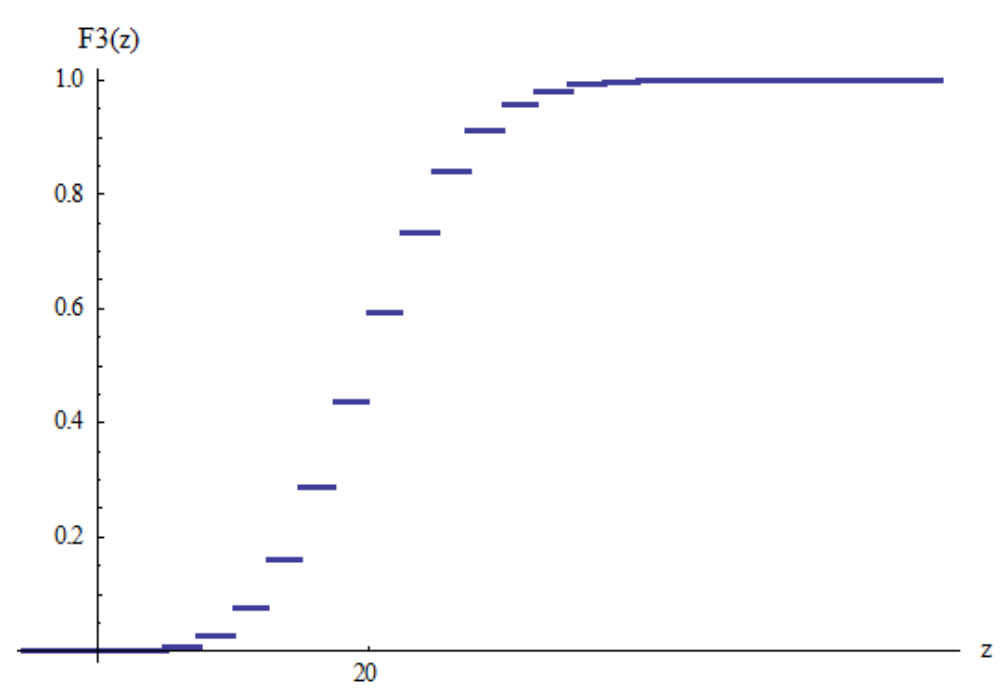

Figure 7. Distribution function of number of points in Test 3 in English (source: own construction)

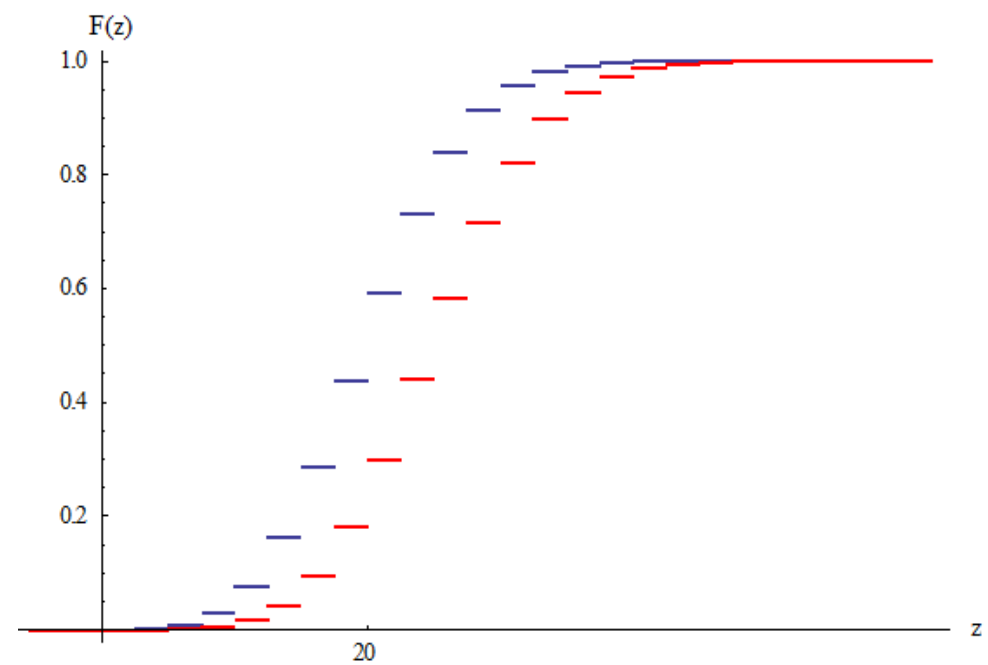

Figure 8. Comparison of the distribution functions of number of points in Test 2 (red) and in Test 3 (blue) in English (source: own construction)

Dispersion of number of points in the Test 3 in English is according to (2)

$D\left(Z_{3}\right)=D(2.5 T)=2.5^{2} \quad D(T)=6.25 * 40 * 0.2 * 0.8=40$

and the standard deviation of number of points in the Test 3 in English is $\boldsymbol{\sigma}_{\mathbf{3}}=\mathbf{6 . 3 2 5}$.

Table 8. Comparison of the tests in English (random choice of answers) (source: own calculation)

\begin{tabular}{|c|c|c|c|}
\hline Entrance examination in English & Test 1 & Test 2 & Test 3 \\
\hline Expected number of points in test & 25 & 25 & 20 \\
\hline Mode & 24 & 25 & 20 \\
\hline Standard deviation & 6.124 & 6.847 & 6.325 \\
\hline Test score more than 10 points & $99.3 \%$ & $98.4 \%$ & $92.4 \%$ \\
\hline Test score more than 20 points & $73.8 \%$ & $70.0 \%$ & $40.7 \%$ \\
\hline Test score more than 30 points & $16.3 \%$ & $17.9 \%$ & $4.3 \%$ \\
\hline Test score more than 40 points & $0.62 \%$ & $1.16 \%$ & $0.1 \%$ \\
\hline
\end{tabular}

Comparison of the Test 1 , the Test 2 and the Test 3 in English is in Tab. 8. For example, test score more than 30 points in Test 3 has $4.3 \%$ of students, since (see Tab. 7) $P\left(Z_{3}>30\right)=1-F_{3}(30)=1-0.956759=0.043241$
Similar problems as in present paper was solved in Klůfa (2015c). There is a comparison of the ways of acceptance students at Prague University of Economics from statistical point of view. Analysis of the entrance exams at Czech University of Life Sciences we can find in Kučera, Svatošová and Pelikán (2015) - relation between results of the entrance exam test and university study results. Analysis of the entrance tests at Comenius University in Bratislava we can find in Kohanová (2012). Correlation between results of the entrance tests (learning potential tests) and study results at University of Pardubice, we can find in Kubanová and Linda (2012). The aim of these papers was a little different.

\section{Conclusions}

The number of questions in the test in English at the Faculty of International Relations at University of Economics in Prague was reduced from 50 to 40 to shorten the test run time. This shortening of the tests had influence on the probability distributions of number of points in the 
tests. The Distribution 1 (the distribution of number of points in the Test 1 in English) and the Distribution 2 (the distribution of number of points in the Test 2 in English) have the same expected value (see Tab. 5). Standard deviation of the Distribution 2 is greater than standard deviation of the Distribution 1 (the mode is greater as well). The probability that number of points in the Test 2 in English exceeds 40 is approximately two times greater (see Tab. 5) than the probability that number of points in the Test 1 in English exceeds 40. Therefore, we designed the Test 3 to improve the probability distributions of number of points in the tests in English. The results of this paper (see Tab. 8 and Fig. 6) show that there has been a significant improvement. For example, the probability that number of points in the Test 3 in English exceeds 40 is much smaller than the probability that number of points in the Test 2 in English exceeds 40 (under of random choice of answers) - see Tab. 8 . The expected number of points in the Test 3 is 20 while the expected number of points in the Test 2 and in the Test 1 is 25 . The Test 3 we can recommend to admission process at the Faculty of International Relations.

\section{Acknowledgements}

The paper was processed with contribution of long term support of scientific work on Faculty of Informatics and Statistics, University of Economics, Prague (IP 400040).

\section{REFERENCES}

[1] Bartoška, J., Brožová, H., Šubrt, T., Rydval, J. (2013) 'Incorporating practitioners' expectations to project management teaching', Efficiency and Responsibility in Education, Proceedings of the 10th International Conference, Prague, pp. 16-23.

[2] Brožová H. and Rydval J. (2014) "Analysis of Exam Results of the Subject Applied Mathematics for IT'”, Journal on Efficiency and Responsibility in Education and Science, Vol. 7, No. 3-4, pp. 59-65, online ISSN 1803-1617, printed ISSN 1803-1617, doi: 10.7160/eriesj.2014.070303.

[3] Flégl M. et al. (2014) "Comparison of Research Engagement of PhD Students at Various Study Programs at CULS Prague: An Introductory Study", Journal on Efficiency and Responsibility in Education and Science, Vol. 7, No. 3-4, pp. 66-73, online ISSN 1803-1617, printed ISSN 1803-1617, doi: 10.7160/eriesj.2014.070304

[4] Flégl M. et al. (2013) "Innovation of Doctoral Studies at the FEM CULS Prague", Journal on Efficiency and Responsibility in Education and Science, vol. 6, no. 4, pp. 265-280, ISSN 1803-1617, doi: 10.7160/eriesj.2013.06040

[5] Hrubý, M. (2016) 'Feedback improvement of question objects', International Journal of Continuing Engineering Education and Lifelong Learning, vol. 26, no 2, pp. 183195. DOI: 10.1504/IJCEELL.2016.076010

[6] Ječmínek, J., Kukalová, G., Moravec, L, Filipová. D. B. (2018) 'Tax courses exams results at FEM CULS Prague evaluation', Efficiency and Responsibility in Education,
Proceedings of the 15th International Conference, Prague, pp. 132-139.

[7] Klůfa, J. (2015a) 'Dependence of the Results of Entrance Examinations on Test Variants', Procedia - Social and Behavioural Sciences, vol. 174, pp. 3565-3571. http://dx.doi.org/10.1016/j.sbspro.2015.01.1073

[8] Klůfa, J. (2015b) 'Analysis of entrance examinations', Efficiency and Responsibility in Education, Proceedings of the 12th International Conference, Prague, pp. 250-256.

[9] Klůfa J. (2015c) "Comparison of The Ways of Acceptance Students at University", Journal on Efficiency and Responsibility in Education and Science, vol. 8, no. 3, pp. 72-76, doi: 10.7160/eriesj.2015.080204

[10] Klůfa, J. (2018) 'Probability comparison ways of acceptance students at university', Efficiency and Responsibility in Education, Proceedings of the 15th International Conference, Prague, pp. s. 155-162. ISBN 978-80-2132858-7. ISSN 2336-744X.

[11] Krejčí, I., Kvasnička, R., Dömeová, L. (2011) , 'Introducing System Dynamics at CULS Prague', Journal on Efficiency and Responsibility in Education and Science, vol. 4, no. 4, pp. 187-196, ISSN 1803-1617, www.eriesjournal.com/pap ers/article_152.pdf

[12] Kubanová, J., Linda, B. (2012) 'Relation between results of the learning potential tests and study results', Journal on Efficiency and Responsibility in Education and Science, vol. 5, no 3, pp.125-134. http://dx.doi.org/10.7160/eriesj.2012. 050302

[13] Kučera, P., Svatošová, L., Pelikán, M. (2015) 'University study results as related to the admission exam results' Efficiency and Responsibility in Education, Proceedings of the 12th International Conference, Prague, pp. 318-324.

[14] Kohanová, I. (2012) 'Analysis of university entrance test from mathematics', Acta Didactica Universitatis Comenianae Mathematics, vol. 12, pp.31-46.

[15] Otavová, M., Sýkorová, I. (2014) 'Analysis of Scores from Mid-Term and Final Test by a Contingency Table', Efficiency and Responsibility in Education, Proceedings of the 11th International Conference, Prague, pp. 527-533.

[16] Otavová, M., Sýkorová, I. (2016) 'Differences in results obtained by students of different faculties', Journal on Efficiency and Responsibility in Education and Science, vol. 9, no 1, pp.1-6. DOI: 10.7160/eriesj.2016.090101.

[17] Poláčková, J., Svatošová, L. (2013) "Relationship of Success in University Study and Admission Exam Results", Journal on Efficiency and Responsibility in Education and Science, vol. 6, no. 4, pp. 281-293, ISSN 1803-1617, doi: 10.7160/eriesj.2013.060406

[18] Premadasa, I. (1993) 'A reappraisal of the use of multiplechoice questions', Medical Teacher, vol. 15, no. 2-3, pp. 237-242.

[19] Rao, C.R. (1973) Linear Statistical Inference and Its Applications, New York: John Wiley

[20] Zhao, Y. (2005) 'Algorithms for converting raw scores of multiple-choice question tests to conventional percentage marks', International Journal of Engineering Education, vol. 21, no. 6, pp. 1189-1194.

[21] Zhao, Y. (2006) 'How to design and interpret a multiple- 
choice-question test: A probabilistic approach', International Journal of Engineering Education, vol. 22, no.

6, pp. 1281-1286.

[22] Zvára, K., Anděl, J. (2001) 'Souvislost výsledku přijímacího řízení s úspěšností studia na MFF', Pokroky matematiky, fyziky a astronomie, vol. 46, no. 6, pp. 304-312. 